\title{
Marsa Matruh revisited: modelling interaction at a Late Bronze Age harbour on the
}

\section{Egyptian coast}

The archaeological remains at Marsa Matruh provide a unique window on cultural interaction in the Late Bronze Age. ${ }^{1}$ An island known locally as Gezirat el-Yehudiyah, but renamed Bates' Island by the University of Pennsylvania Expedition I in the 1980s in honour of Oric Bates, a Harvard scholar who visited the area for a few months in 1913-14. The island is located in a shallow lagoon, the northern rim of which offered the prospect of shelter during Mediterranean storms. The Late Bronze Age remains have been extensively described, ${ }^{2}$ and a brief account will suffice here. Four different activity areas are discernible, running north south along the spine of the island. ${ }^{3}$ The main storage area lay on the northern part of the island, identified by a number of Cypriot pithoi and Canaanite jars. A series of walls run through the area, but they do not connect in a coherent fashion; there are also a few hearths, as well as a midden of animal and fish bones and sea shells. A cooking area lays to the south of this, but the archaeology was heavily disturbed, first by the construction of a fishermen's hut over them and later by the destruction of the same in World War II. Further along the ridge was a series of very small rooms, apparently plastered. At least one of them was paved with flat stones. This cluster of rooms may have been protected from winds from the west by a sheltering wall, but this may also have been an access ramp, although to what is not clear. A final group of rooms or semi-open areas lay at the southern tip of the island. Identified by the archaeologists as a workshop, it was in this area that small bronze items were fashioned, as indicated by the presence of crucibles and metal waste. ${ }^{4}$

Given its isolated location, the material remains found on Bates' Island is one of the rare occasions where pots can be held to more or less equal people, albeit with the caveats that form a large part of the argument here. The island was a place of encounter for at least three

\footnotetext{
${ }^{1}$ Oric Bates, The Eastern Libyans (London, Macmillan, 1914); Donald White, Marsa Matruh. The University of Pennsylvania Museum of Archaeology and Anthropology Excavations on Bates's Island, Marsa Matuh, Egypt 1985-1989, volumes I-II (Philadelphia: INSTAP, 2002); Linda Hulin, “A Final Summary of the Evidence”, in Donald White Marsa Matruh. The University of Pennsylvania Museum of Archaeology and Anthropology Excavations on Bates's Island, Marsa Matuh, Egypt 1985-1989, volumes I-II (Philadelphia: INSTAP, 2002), pp. $169-78$.

2 White 2002; Linda Hulin, "Marsa Matruh 1987, Preliminary Ceramic Report”, Journal of the American Research Center in Egypt 26 (1989): 115-26.

${ }^{3}$ White, 2002: 35-84.

${ }^{4}$ White, 2002: 72-5.
} 
different groups: mariners, Libyans and Egyptians. Discussion in the initial publication emphasised the mariners, providing for the island a unique window into sailors' lives. ${ }^{5}$ Other discussions sought to bring the Libyans closer to centre stage. ${ }^{6}$ This paper considers the practicalities of the activities on the island and seeks to balance the roles and spheres of activities of all three groups (Figure 1).

\section{Mariners}

The island is well placed on the eastern Mediterranean gyre. Sailing from southern Crete, ships would make landfall in Cyrenaica and progress eastwards to the Delta, and then along the Levantine coast. A northern wind blows in winter towards Crete, allowing some connection between the two at this time. ${ }^{7}$ In any event, this section of the north African coast would have seen ships passing with some regularity during the sailing season, even if most did not put in to the lagoon at Marsa Matruh.

It seems reasonable to assume that the facilities on the islands were constructed by and for the use of passing mariners. The walls were constructed out of stone with a rubble fill, held together by a mud mortar, with possibly a lightweight wattle superstructure. Even though it is not possible to identify the origin of the people who used the island based upon the construction of its architecture, because this method of building was not regionally specific within the eastern Mediterranean; however, we can say that it was not Egyptian nor, as far as we can tell from the limited evidence, Libyan. ${ }^{8}$

\footnotetext{
${ }^{5}$ Hulin, 2002.

${ }^{6}$ [David Conwell, “On Ostrich Eggs and Libyans. Traces of a Bronze Age people from Bates' Island, Egypt”, Expedition 29, iii (1987): 25-34. Seth Richardson, "Libya Domestica: Libyan trade and Society on the Eve of the Invasion of Egypt", Journal of the American Research Center in Egypt 36 (1999): 149-64. Linda Hulin, "Pragmatic technology: issues in the interpretation of Libyan material culture", in Intercultural Contacts in the Ancient Mediterranean, eds K. Duistermaat and I. Regulski [Orientalia Lovanienia Analecta 202] (Leuven: Peeters, 2011), pp. 101-14.

${ }^{7}$ L. Vance Watrous, Kommos III. The Late Bronze Age Pottery (Princeton: Princeton University Press), figs 1011.

${ }^{8}$ Carter identified circular huts in Cyrenaica, and similar circles were found in the squatter levels at Zawiyet Umm el-Rakham. They are built of stone, but without mud-mortar; there is a possibility that they were animal pens, in which case a Libyan style of architecture has not been identified. Theresa Carter, "Reconnaissance in Cyrenaica”, Expedition 5, iii (1963): 18-27. For Libyan squatter levels in the fortress of Zawiyet Umm-elRakham, see Fiona Simpson, "Evidence for Late Bronze Age Libyan Culture at the New Kingdom Egyptian Fortress of Zawiyet Umm el-Rakham", in Current Research in Egyptology 2000, eds Angela McDonald and Christina Riggs (Oxford: (Oxbow Books, 2000), pp. 97-102. Fiona Simpson, "Evidence for a Late Bronze Age Libyan presence in the Egyptian fortress at Zawiyet Umm el-Rakham”, PhD thesis, Liverpool University, 2002.
} 
The small size of the rooms, ${ }^{9}$ was not conducive for long-term occupancy, nor does the stratigraphy, which is limited, suggest extended stays. However, the installation of Cypriot pithoi in the northern area and the presence of the admittedly more portable Canaanite jars and Mycenaean stirrup jars, suggests that provisions were laid in for at least short stays. The presence of Cypriot, Minoan and Mycenaean cups and bowls, alongside Cypriot cooking vessels and Canaanite and Cypriot lamps in the central area, were surely the remains of personal possessions rather than cargo. ${ }^{10}$ Their presence suggests either a range of mariners from different locations across the eastern Mediterranean, or a geographically more limited group that collected these items as they travelled around the region, with the obvious caveat that these objects almost certainly do not represent a single event, but are the detritus of numerous visitations. In either case, one has to wonder exactly how the island was organised: could all ships avail themselves of the contents of the jars? Was their an honour system of partial replenishment as payment? Was there a controlling authority? Was someone placed there to guard or administer goods? How was authority maintained?

\section{Libyans}

The presence of chert objects that stands within a wider Libyan tradition stretching from Kharga oasis to the wadi Kambut in Libya, ${ }^{11}$ and also ostrich egg shell fragments, brings another group to the fore: the Libyans. ${ }^{12}$ Our knowledge of the Libyans is heavily dependent upon Egyptian written and visual sources, for the archaeological record is scant. Artists emphasised a stereotypical otherness, detailing such un-Egyptian characteristics in males as ostrich feathers worn in long hair, tattoos, penis sheaths or genital exposure, and the wearing of brightly coloured skins of fabric cloaks. ${ }^{13}$ There may well have been some truth to this, similar dress codes are shown in images from the Tadrart Acacus, albeit from around 1,000

\footnotetext{
${ }^{9}$ Measurable rooms averaged less than $2 \mathrm{~m}^{2}$ in size. White, 2002: 78-9.

10 Hulin, 2002: 192-3, context lists for F4 III.

11 Linda Hulin, Jane Timby, Ahmed Muftah and Giuseppina Mutri, "Western Marmarica Coastal Survey 2010: preliminary report”, Journal of Libyan Studies 41 (2010): 155-62.

12 See Conwell 1987; Steven Snape, “Of Ostrich-Eggs and Kings: the Topos and Mimesis of International relationships in the Late Bronze Age”, in Shifting Boundaries, ed. B. Finlayson [Amman: Institute for InterFaith Studies, 2012], pp. 90-115. Also Norman de Garis Davies, The Rock Tombs of Amarna volume III [Archaeological Survey of Egypt Memoir 15] (London: Egypt Exploration Society, 1905), pl. XL, showing Libyans bringing ostrich eggs to court.

13 William Cooney, "Egypt's encounter with the west: race, culture and identity”, in Current research in Egyptology 2009: proceedings of the tenth annual symposium Liverpool University 2009, eds J. Corelli, D. Boatright and C. Malleson (Oxford: Oxbow Books (2010), pp. 43-52.
} 
years earlier. ${ }^{14}$ Representations of Libyans wearing Egyptian-style kilts indicates that, outside this narrative, a more flexible visual identity was employed by at least some Libyans. ${ }^{15}$ There is some correlation between named groups and visual style, but not with enough consistency to unable scholars to draw a clear link between the two. ${ }^{16}$ Relations between the Egyptians and Libyans until the time of Amenophis III has been described as a mixture of low-level trade and low-level threat, ${ }^{17}$ after which aggressive encounters dominate the narrative, as the Libyans began a movement that would ultimately culminate in the occupation of the Delta in the Third Intermediate Period. From that point, Libyans appear as forced to labour in construction projects under Amenophis III and Rameses II. ${ }^{18}$

Certainly the number of named Libyan groups increased in the New Kingdom, although Egyptian use of them is both vague and precise. Added to the Tjemeh and the Tjehenu, were the Meshwesh and the Libu. We do not know the extent, if any, of social links between the different social groups. New, previously unheard of tribes, such as the Kehek and the Soped appear in a minor capacity in war alliances, ${ }^{19}$ but whether this means that independent groups banded together for specific campaigns or whether they represent allied groups in peaceful pursuits is not known. ${ }^{20}$ Were contacts social or economic? Were marriage alliances contracted?

We can gather the relative proximity to Egypt of various groups, but not the distance between them or their location. ${ }^{21}$ The Meshwesh and the Libu, were most probably located in Cyrenaica, while the Tjemeh occupied the desert closest to the Nile, circulating between

\footnotetext{
${ }^{14}$ Malika Hachid, Les Premiere Beberes entire Mediterranee, Tassili et Nil (Aix-en-Provence: Edisud, 2000).

${ }^{15}$ Norman de Garis Davies, The Rock Tombs of Amarna volume I [Archaeological Survey of Egypt Memoir 13] (London: Egypt Exploration Society, 1905), pl. XV. The Rock Tombs of Amarna volume III [Archaeological Survey of Egypt Memoir 15] (London: Egypt Exploration Society, 1905), pl. XXXI.

${ }^{16}$ David O’Connor, “The Nature of Tjemhu (Libyan) Society in the Later New Kingdom”, in Libya and Egypt c. 1370-750 B.C., ed. A. Leahy (London: SOAS/Society for Libyan Studies, 1990), pp. 47-57.

${ }^{17}$ Steven Snape, "A stroll along the corniche? Coastal routes between the Nile Delta and Cyrenaica in the Late Bronze Age", in Desert Road Archaeology in Ancient Egypt and Beyond, eds F. Förster and H. Riemer (Cologne: Heinrich Barth Institut, 2013), p. 440.

${ }^{18}$ Wolfgang Helck, Urkunden der 18. Dynastie, Heft 20, Historische Inschriften Amenophis III (Berlin: Akademie Verlag, 1957): 1656. Alexandre Barsanti and Henri Gauthier, "Stèles trouvées à Ouadi Es-Sabouâ (Nubie)”, Annales du Service des Antiquités de l’Égypte 11 (1911): 64-86.

${ }^{19}$ See Bates, 1914: 46-7.

${ }^{20}$ Steven Snape, 2013: 442 and fig. 3.

${ }^{21}$ Contra Bates, 1914: 46-51, map II, Alan Rowe, A history of ancient Cyrenaica: New light on AegyptoCyrenaean Relations (Cairo: IFAO, 1948).
} 
oases from the Fayyum to the second cataract. The Tehenu would seem to have occupied the space to the north of the Tjemeh, although by this time the Egyptians did not consistently distinguish between the two. An inscription from the main gate at Zawiyet Umm el-Rakham, implies that it is situated in the hill country of the Tjemeh and the wells within them, but our understanding of the relations between different Libyan groups is weak. ${ }^{22}$ The presence of fragments of ostrich eggs, a desert item, suggests either interaction between groups that circulated in the desert and those that occupied the coast, or to long-range activity on the part of the Tjemeh.

Taken as a whole, "Libyan” territory was environmentally diverse. The Gebel Akhdar in the west is a perennially watered plateau rising to over $600 \mathrm{~m}$, and around $400 \mathrm{~mm}$ of rain (and snow) falls there annually. From Tobruk to Bardiyah the availability of cultivable soil reduces, with water being captured in seasonal wadis. However, from Bardiyah to Marsa Matruh the gebel draws back to form a plain some $20 \mathrm{~km}$ wide, with deep soil, and an average of $144 \mathrm{~mm}$ of rain, concentrated from October to January, the last area capable of supporting agriculture before the Delta. ${ }^{23}$ An aquifer in the limestone bedrock provides a year-round water supply accessed through wells; the fortress at Zawiyet Umm el-Rakham had two ${ }^{24}$ and doubtless this would have been possible at other points along the coast.

It is arguable that the area around Marsa Matruh would have been, in terms of inter-tribal relations, on the periphery of the Libyan world. The heartland lay to the west, where the environment was able to support a larger population. Certainly, it was from the west that the aggression against Egypt was co-ordinated, and to the west that the defeated Libyan leader Meryey son of Ded fled. ${ }^{25}$ It was in the west that Egyptians located the towns of the towns, although that conception may have been highly inaccurate. ${ }^{26}$

\footnotetext{
22 O’Connor, 1990: 31-32 laments the slipperiness of modern nomenclature of tribes or bands, and the implications they have for our conception of inter-group relations.

23 Muhammad Safi el-Din, Landforms of Egypt (Cairo: American University Press, 1971); White, 1999: 932; Snape 2013: 445-6. Daniel Hounsell, “The occupation of Marmarica in the Late Bronze Age: an archaeological and ethnographical study”, PhD thesis, University of Liverpool, 2002, pp. 11-15.

24 Snape, 2013: 446-7.

25 Bates, 1914: 221-2.

${ }^{26}$ O’Connor, 1990: 63-6.
} 
Marginal areas around Marsa Matruh may have been to the Libyans — and it would have become even more so once Ramesses II established the fortress at Zawiyet Um el-Rakham, consigning them to an existence on the wrong side of a border - capable of supporting a limited population at a subsistence level. Thus, it would have been possible to grow seasonal crops, such as barley. A stela from the fortress suggests that the Egyptians Libyan labour in the fields around the fort, growing grain and flax. ${ }^{27}$ The remains of sheep, goat and cattle were all of which were present on Bates' Island. ${ }^{28}$ The booty lists of Merenptah and Rameses III include large herds taken from the Libyans. ${ }^{29}$ Marine sources may also have been exploited, since fish bones were also found on the island, and fish hooks were found there, but they may equally have been brought by the mariners; neither scenario precludes the other. $^{30}$

However, it is unlikely that, if left to themselves, the population who lived around Marsa Matruh would have confined themselves to the coast. Inhabitants of coasts adjacent to semiarid and arid landscapes operate a mixed economic strategy oscillating between agriculture and pastoral nomadism as the seasons dictate; the ever-present likelihood of short or longterm drought necessitates the maintenance of social, or even familial links between practitioners. Behnke reported that young men in eastern Cyrenaica took herds into the desert in winter leaving older men to look after crops on the coast. ${ }^{31} \mathrm{Up}$ until the First World War, herders from Marsa Matruh wintered their sheep in Siwa oasis, the journeys to and from the oasis being undertaken in very narrow windows of time when the herds could move between short-lived grazing spot in the desert. In the fifth century BC, Herodotus reported upon a similar transhumance strategy in Libya; ${ }^{32}$ images of cattle are found carved into the rock at Jaghbub oasis, and a breed of cattle known as meshwesh-cattle were traded to the Egyptians

\footnotetext{
27 Steven Snape, “A New Ramesside Stela”, in Ramesside Studies in Honour of K.A. Kitchen, eds Mark Collier and Steven Snape (Bolton: Rutherford Press, 2011), pp. 123-6.

28 David Reese and Mark Rose, “Organic remains from the island and adjacent areas”, in Donald White Marsa Matruh. The University of Pennsylvania Museum of Archaeology and Anthropology Excavations on Bates's Island, Marsa Matuh, Egypt 1985-1989, volumes I-II (Philadelphia: INSTAP), pp. 73-108.

29 O’Connor, 1990: 96; KRI IV: 38.5, KRI V: 53.14-54.8.

30 Reese and Rose, 2002.

${ }^{31}$ Roy Behnke, Herders of Cyrenaica: ecology, economy and kinship among the Bedouin of eastern Libya [Illinois studies in Anthropology 12] (Chicago: University of Illinois Press, 1980): 49-73.

32 Herodotus, Historia IV.
} 
in the nearer oases in the Old Kingdom. ${ }^{33}$ Closer to home, there is evidence for the exploitation of stands of wild barley in the wadis that cut through the gebel to the south, while chert scatters indicate the movement of Libyans through this semi-arid table land, up to $50 \mathrm{~km}$ away from the coast. ${ }^{34}$

Encounters between the mariners and the Libyan population may be characterised as lowlevel opportunistic trade. ${ }^{35}$ If the mariners wanted ostrich eggs, they were able to offer metal items in exchange, desirable items for north Africa has no metal ores of its own. The southern cluster of rooms on Bates' Island included, as well as small rooms, a series of more or less open areas defined by a mixture of walls and screens that may have been shifted according to the prevailing wind. ${ }^{36}$ Scattered across the area were remains of crucibles, mostly made of clay, but with one stone example, as well as the metal detritus of making simple tools on the spot, in this case, arrow heads, fish hooks and pins.

The original population envisaged the Libyans as recipients of this technology, ${ }^{37}$ with the mariners in control of this process: they brought the crucibles and the metal and made items to order on the spot. Similar activities took place at Zawiyet Umm el-Rakham in postEgyptian squatter phases, and Simpson argued that this technology was beyond the capabilities of the local population, largely on the grounds that the lithic technology at the site was fundamentally "Neolithic", and therefore technologically stagnant, ${ }^{38}$ as opposed to fit for purpose. This was challenged by this writer, who argued that the Libyans had learned a "pragmatic" technology oriented towards the maintenance of chariots listed in Egyptian booty lists, their associated horse trappings, and the repair of swords used by the Libyans in their capacity of mercenaries and, later, credible members of the "Sea Peoples" fighting

\footnotetext{
${ }^{33}$ Ludwig Borchardt, Das Grabdenkmal des Königs Sá3hu-R` (Leipzig: Wissenschaftliche Veröffentlichungen der Deutschen Orient-Gesellschaft, 1910): figs 11-12.

${ }^{34}$ Thomas Vetter, Anna-Katharina Rieger and Heike Möller, "Water, routes and rangelands: Ancient traffic and grazing infrastructure in the eastern Marmarican (northwestern Egypt)", in Desert Road Archaeology, F. Förster and H. Riemer (Cologne: Heinrich Barth Institut, 2013), pp. 445-484.

${ }^{35}$ Donald White, "Water, wood, dung and eggs: reciprocity in trade along the LBA Marmarican coast", in MELETEMATA. Studies in Aegean Archaeology presented to Malcolm H. Wiener as he enters his 65th. year vol. III, eds P. Betancourt, V. Karageorghis, R. Laffineur and W.-D. Niemeier [Aegaeum 20] (Liege: University of Liege, 1999), pp. 931-6.

${ }^{36}$ White, 2002: 72-5.

${ }^{37}$ Hulin, 2002. White, 1999.

${ }^{38}$ Simpson, 2002: 195.
} 
force. ${ }^{39}$ The presence of a crucible on Bates' Island made of local fabric seemed to support this, plus the need, noted by White, to gather together fuel (dung) for the casting process. ${ }^{40}$

\section{Egyptians}

The Egyptians constituted the third presence on Bates’ Island, identified through the presence of pottery. Most of the Egyptian ceramic record consists of shallow bowls, but there are also single examples of cups, jars and juglets. ${ }^{41}$ They were found in the same contexts as ceramics from the eastern Mediterranean in the central cooking area, and most, commonly, in the southern area in association with crucibles and the detritus of small object production. The precise chronology of activity on the island is slightly confused, certainly in the latter half of the fourteenth century, and the Egyptian materials dates either to just before the establishment of Zawiyet Umm el-Rakham or, most likely is contemporary with it. The earlier date would imply an Egyptian presence somewhere within the vicinity that has not yet been identified. In the context of this article, the precise date matters less than the modes of interaction between the mariners, the Libyans and the Egyptians on the island.

Snape argued that was a fourteenth century trading station, operating in free circumstances, between mariners and Libyans. He suggested that one of the many reasons for the foundation of Zawiyet Umm el-Rakham was to ensure the continuity of this trade, which may have been threatened by the eastward expansion of the Meshwesh and Libu, disrupting the more cordial trade relationships between the local Libyan population and the mariners. ${ }^{42}$ The fortress was not located at the lagoon at Marsa Matruh for military reasons: it was situated where the width of the coastal plain narrows, and thus at a pinch point for Libyans moving eastwards along the coast. This was a strategic compromise borne of necessity, for the deeper waters in the lagoon at Marsa Matruh allowed for the arrival of the menesh-ships that would have brought supplies to the fortress; as White and White noted, the coastline offers, in general, very few opportunities for ships. ${ }^{43}$ Certainly Aghiba, the nearest anchorage to Zawiyet Umm el-Rakham, is too shallow, although ships could possibly have anchored further off, with

\footnotetext{
39 Hulin, 2011.

40 White, 1999.

41 Hulin, 2002: 192-3.

42 Snape, 2013: 452-3.

43 Donald White and Arthur White, “Coastal Sites of North-East Africa: The Case Against Bronze Age Ports”, Journal of the American Research Centre in Egypt 33 (1996): 11-30.
} 
goods being transported in small barges or by individuals wading through the shallows. No remains have been found in the sea, however.

One of the magazines in the fortress at Zawiyet Umm el-Rakham contained Canaanite and Mycenaean storage jars alongside Egyptian ones, as well as a small Mycenaean pilgrim flask, so-called, and Cypriot base-ring lentoid flasks and even base-ring teapots, the latter rarely found abroad. ${ }^{44}$ Given the lack of an anchorage close to the fortress, the presence of these items would support the notion that Bates' Island was the point of access for these goods. Certainly, it is difficult to imagine that the Egyptians, so far from the Nile valley, would decline the opportunity to such acquire goods.

\section{The control of Bates' Island}

One may imagine four different scenarios for the activities on Bates' Island. The first is trade between mariners and Libyans, the mariners taking the lead in the exchange of ostrich eggs for metal items, made on the spot, and possibly for water and food. The same actors are present in the second scenario, but with the Libyans taking an active role in the preparation for the encounter (making at least one crucible, gathering fuel), and possibly taking part in the production. This does not imply great intentionality on the part of either party. The mariners could have carried the wherewithal to make small metal items in order to maintain their ship, or to fish on their own behalf, but they could also have been prepared to engage in petty exchange with Libyans, or others on their route. For their part, the Libyans could have either gathered dung when the ship came into the lagoon, or simply used some of their own supply gathered from their own herds. In the third scenario, mariners engaged in exchange with both the Libyans and the Egyptians, with Egyptians there as traders. In the final scenario, activities took place on the island under the aegis, if not the active control, of the Egyptian military authority (contra Snape, above).

Common to all scenarios is the view of Bates' island as a facility for short stays on the island by mariners, in part as a shelter in times of bad weather, and in part as a trade facility. Kuhlmann, disputes the latter, arguing that trade could never have been a motivator for exchange with the Libyans, as the area was too environmentally impoverished to produce

\footnotetext{
${ }^{44}$ Steven Snape, “Zawiyet Umm el-Rakham and Egyptian foreign trade”, in Sea Routes... Interconnections in the Mediterranean 16th-6th c. BC, eds. Nicholas Stampolides and Vassos Karageorghis (Athens: A.G. Leventis Foundation, 2003), pp. 63-70.
} 
anything of interest to the mariners. ${ }^{45}$ He regarded the presence of Aegean and Cypriot pottery as indicative of the presence of non-Egyptian troops at the fort. ${ }^{46}$ If this was indeed the case, then the ostrich egg shell on the island should perhaps be seen as acquired, certainly from the Libyan interior, as a secondary exchange item. The mariners would surely have recognised the worth of the ostrich eggs in the eastern Mediterranean where they were prized; that being so, it is difficult that their exchange partners, whoever they were, would have dismissed it as a quotidian item.

Kuhlmann raises the point that the fact that the mariners preferred to establish themselves on Bates' Island indicates a certain wariness on their part, which he compares to the tale of Odysseus plundering Egypt from the safety of Pharos Island. ${ }^{47}$ Certainly the island was, in the Late Bronze Age, even smaller than it is now, no more than $43 \mathrm{~m}$ along its spine and little ore than $8 \mathrm{~m}$ at its widest extent. It was not a cramped space, but nor was it spacious, and it was certainly, from a practical view, inconvenient. Visitors, Egyptian or Libyan, would have had either to swim, or possibly wade, to the island or make use of a boat, arguably the latter, since fuel, and possibly ceramics and food, would have had to be kept dry in passage over. It would, one feels, have been simpler to meet on the shore, to engage in beach trade.

However, the mariners could have preferred to stay on the island for a number of reasons, only one of which was for personal safety. Related to safety might have been the concern to protect their main cargo, which they may not have owned themselves and for which they would have been responsible. They may also have been enclaved by the Egyptian authorities, who may have sought to regulate the activities of the mariners and the interaction of the subject Libyans with outsiders. In view of the subsequent present of Libyans in the alliance of Sea Peoples this may not have been an unreasonable position, although the contribution of the Libyan fighting force is most likely to have been gathered from the "free" lands further to the west. The Egyptians may have wished to limit the movement of Libyans, particularly those in search of work not under Egyptian control.

\footnotetext{
${ }^{45}$ Klaus Kuhlmann, "Roman and Byzantine Siwa: Developing a Latent Picture”, in Life on the Fringe: Living in the Southern Egyptian Deserts during the Roman and early Byzantine Periods, ed. O. Kaper (Leiden: CNWS Publications Leiden University, 1988), pp. 71-4.

${ }^{46}$ Klaus Kuhlmann, "The 'Oasis Path' or the Issue of Desert Trade in Pharaonic Times”, in Tides of the Desert -- Gezeitender Wüste. Contributions to the Archaeology and Environmental History of Africa in Honour of Rudolph Kuper [Africa Praehistorica 14] (Cologne: Heinrich Barth Institut, 2002), p. 126, n. 1, 2.

${ }^{47}$ Klaus Kuhlmann, "The realm of the 'two deserts': Siwah Oasis between east and west”, in Desert Road Archaeology in Ancient Egypt and Beyond, eds F. Förster and H. Riemer (Cologne: Heinrich Barth Institut, 2013), p. 148.
} 
As noted earlier, the food consumed on the island appears to be a mixture of maritime fish and shell, which could have been brought by the sailors themselves. The presence of skull and pelvis bones of sheep and goat suggests that was meat acquired locally. Some of this may reflect mariners' meals. However, the mixture of marine and local food may indicate shared meals, and, since most exchange is sealed by a meal, however informal, this suggests interaction between actors on land and visitors to the island.

There is, in the end, no way of proving the validity of any one of these scenarios over the other. This writer is inclined to the view that Bates' Island serves as a trading point for mariners, Libyans and Egyptians, and sees no contradiction between Kuhlmann's view of the impoverishment of the area and intentional — if unplanned - trade between the Libyans and the mariners. That ultimately, did not prove to be a driving force in Libyan economic development, it is a testament to its limited scale, a state of affairs doubtless part of Egyptian official policy. However, the presence of the Egyptians may well have guaranteed the smooth functioning of the island as a shelter, actively regulating the use or replenishment of resources by different visitors in any one sailing season. If the lagoon was the main port for the fortress at Zawiyet Umm el-Rakham, then the Egyptians may well have availed themselves of the facilities at times, the scarcity of Egyptian storage vessels (as opposed to open bowls, a standard ration shape) being due to the fact that they were sent on to the fortress itself. The variety of possible interpretations is a testament to the uniqueness of the material record on the island, not just in the Late Bronze Age, but indeed, in the first millennium as well.

Linda Hulin, Oxford Centre for Maritime Archaeology, University of Oxford. 


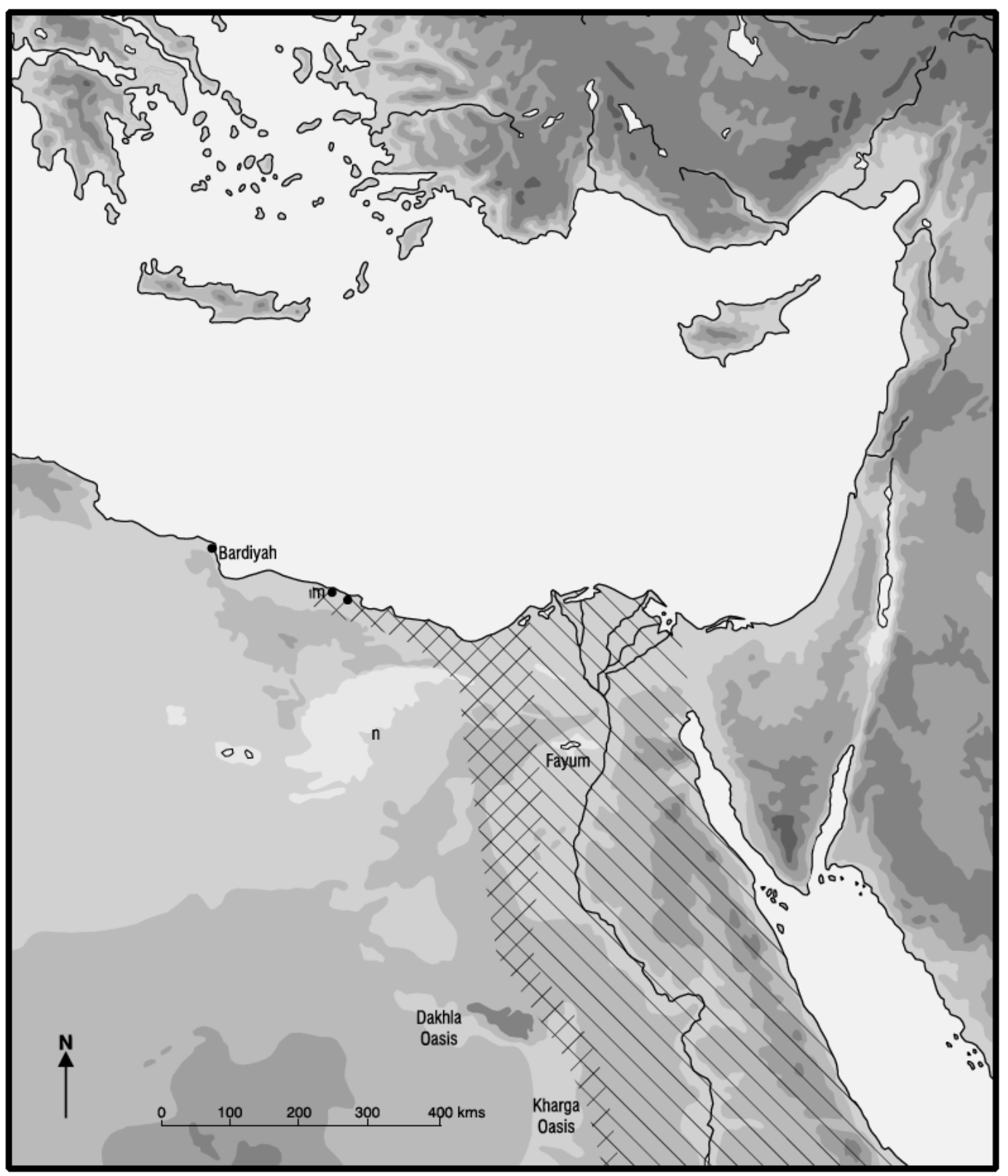

Figure 1: Map illustrating the areas of activity of the three groups present on Bates' Island. Drawing: C. Hulin. 